\title{
THE POWER OF ${ }^{14} \mathrm{C}$ MEASUREMENTS COMBINED WITH CHEMICAL CHARACTERIZATION FOR TRACING URBAN AEROSOL IN NORWAY
}

\author{
L A CURRIE*, G A KLOUDA*, JØRGEN SCHJOLDAGER**, \\ and THOMAS RAMDAHL +
}

\begin{abstract}
Changing fuel patterns and increased awareness of health effects from combustion aerosols have generated considerable interest in the use of ${ }^{14} \mathrm{C}$ as a biogenic-fossil aerosol source discriminator. Prior studies in the US demonstrated the importance of ${ }^{14} \mathrm{C}$ measurement for estimating the wood-burning contribution to urban aerosols. The present work treats a specific air-pollution problem in the town of Elverum, Norway where large wintertime concentrations of aerosol carbon and polycyclic aromatic hydrocarbons (PAH) were suspected to come from residential wood combustion (RWC). The problem was significant in that up to $50 \mu \mathrm{g} / \mathrm{m}^{3}[\mathrm{C}]$ and $490 \mathrm{ng} / \mathrm{m}^{3}[\mathrm{PAH}]$ were found during pollution episodes. Samples collected during two winters were analyzed for ${ }^{14} \mathrm{C}, \mathrm{C}, \mathrm{PAH}$, and several elements in the fine fraction $(<3 \mu \mathrm{m})$ aerosol. Source apportionment based on these species indicated an average of ca $65 \%$ RWC-carbon $\left({ }^{14} \mathrm{C}\right)$, ca $5 \%$ fine particle mass from motor vehicles $(\mathrm{Pb})$, but negligible contributions from heavy fuel oil $(\mathrm{Ni}, \mathrm{V})$. Patterns of ${ }^{14} \mathrm{C}$ and total $\mathrm{C}$, examined as a function of temperature and $\mathrm{PAH}$, indicated large increases in RWC aerosol on the coldest days, and a major RWC contribution to the PAH fraction. Patterns with inorganic species implied multiple tracer sources, and one important case of long-range transport.
\end{abstract}

\section{INTRODUCTION}

Radiocarbon has become recognized as the essential isotopic tool for quantifying the fossil and biospheric carbon contents of chemicals in the environment. One of the most important such applications is the tracing of sources of atmospheric aerosols, particularly those resulting from human activities (Currie, Klouda \& Voorhees, 1984). Carbonaceous aerosols are significant in terms of their potential influence on health, visibility, and climate; they are formed whenever (organic) fuel is subject to incomplete combustion. In populated areas, therefore, atmospheric carbon derives from stationary power production (coal, oil), motor vehicles, and residential heating (wood, oil, coal). The objective of the research herein reported was to apportion the aerosol arising from such sources, using ${ }^{14} \mathrm{C}$ and chemical tracers, for a small town in Norway which was experiencing serious winter-time pollution (Ramdahl et al, 1984).

Residential wood combustion (RWC) was suspected to be a primary source of the elevated carbonaceous aerosol in the town of Elverum. The application of ${ }^{14} \mathrm{C}$ to the study of this type of problem was first reported by Currie, Klouda and Cooper $(1980) ;{ }^{4} \mathrm{C}$ has subsequently become the accepted tracer for RWC. It should be noted also that in the intervening years, RWC pollution has become a problem of international significance. The shortage of petroleum in the mid-1970's led to a renewed interest in wood as a fuel, and problems associated with its use have been reflected in a number of conferences on the topic (Cooper \& Malek, 1982; APCA, 1982), as well as the imposition of regulations-especially in populated areas subject to winter-time inversions and quite cold temperature, such as high alti-

\footnotetext{
Contribution of the National Bureau of Standards; not subject to copyright

* National Bureau of Standards, Gaithersburg, Maryland 20899

** Norwegian Institute for Air Research, 2001 Lillestr $\phi m$, Norway

+ Central Institute for Industrial Research, Blindern, Oslo 3, Norway
} 


\section{ELVERUM}

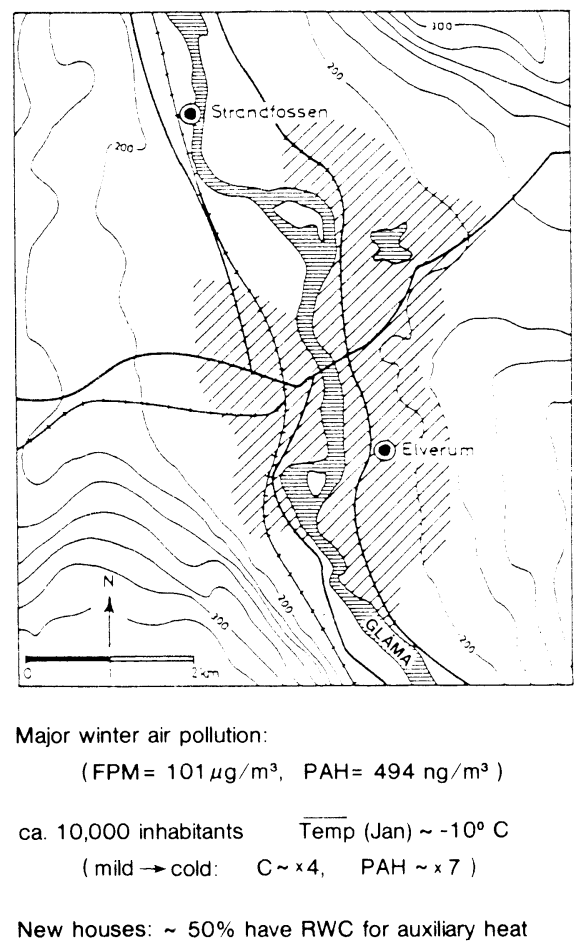

Fig 1. Elverum, Norway - contour map and background facts. FPM = fine particle mass; $\mathrm{PAH}=$ polycyclic aromatic hydrocarbons; $\mathrm{RWC}=$ residential wood combustion. (FPM and PAH represent maximum observed concentrations.)

tude cities and ski valleys (Zak et al, 1984). Wood as a fuel is a more significant pollutant source, compared to liquid or gaseous fuels, because of its typically inefficient combustion: the ratio of particle to heat production for wood is higher by factors of 20 to 60 (Lipfert \& Dungan, 1983).

The site of the study, together with some of its characteristics are indicated in Figure 1. Elverum, which lies ca $120 \mathrm{~km}$ north of Oslo, is vulnerable to RWC pollution because it is situated in a shallow river valley, it is subject to cold temperatures in winter, and it has a substantial fraction of new housing incorporating wood stoves as a secondary heat source. Though the population is small compared to Oslo, the wintertime carbonaceous aerosol pollution levels are comparable.

Apportionment of the aerosol sources in Elverum was based on Receptor Modeling, ie, the use of chemical and isotopic "fingerprints" in the ambient aerosol compared to that of known sources to assess quantitative source contributions (Stevens \& Pace, 1984). Table 1 indicates some tracers which may be appropriate for this task. Important points to be drawn from the table are: 1) that the combined use of ${ }^{14} \mathrm{C}$ and selected elemental 
TABLE 1

The problem: apportioning combustion aerosols*

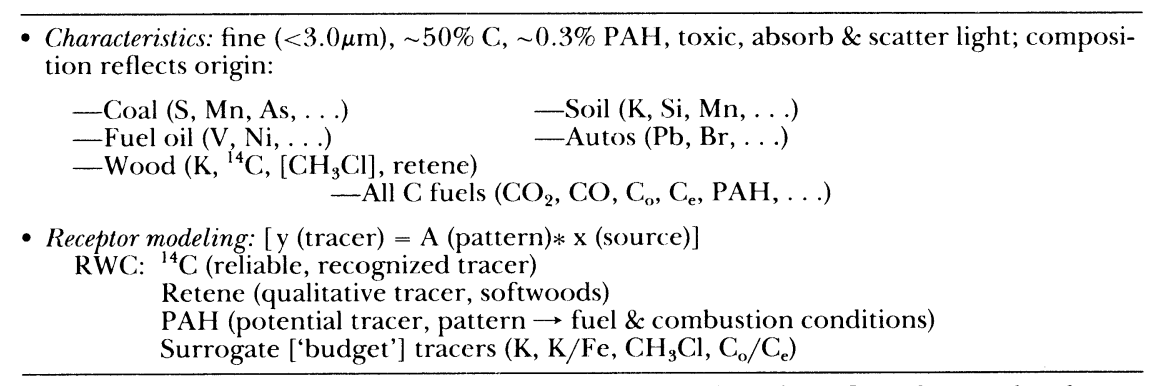

$* \mathrm{RWC}=$ Residential Wood Combustion; $\mathrm{C}_{\mathrm{o}}=$ organic carbon; $\mathrm{C}_{\mathrm{e}}=$ elemental carbon

tracers makes possible the apportionment of the prime combustion aerosol sources, 2) that multicomponent classes of pyrosynthetic organic compounds, such as the polycyclic aromatic hydrocarbons (PAH), offer potential source apportionment through their relative abundance patterns, and 3 ) that ${ }^{14} \mathrm{C}$ is the only direct RWC tracer, which is not subject to some of the assumptions involved in the use of the less expensive ('budget') tracers commonly applied to the problem. Retene (1-methyl-7-isopropyl-phenanthrene) is a special molecular tracer, in that it is source-specific. Unlike most of the $\mathrm{PAH}$, retene is a pyrodegradation product, coming from relatively low temperature dehydrogenation of abietic acid, a biosynthetic component of softwoods, such as spruce and pine (Ramdahl, 1983). Though unique as a tracer for these sources, retene must be considered qualitative, as its production and survival depend upon the temperature history of the combustion process.

\section{DESIGN AND RESULTS OF THE ELVERUM STUDY}

\section{Background Information; Average Results}

During the two winter seasons, 1980-81 and 1981-82, fine particle aerosols were sampled as a function of time, temperature, and wind velocity. Total carbon, ${ }^{14} \mathrm{C}$, anion, and elemental concentrations were measured during both winter seasons; these were supplemented by organic and mutagenicity measurements during the second winter season. Measurements of ${ }^{14} \mathrm{C}$ were all performed at NBS using miniature gas counting techniques as described in Currie et al (1983). Sample sizes were ideal for this method of counting, as they ranged from ca 5 to $55 \mathrm{mg}-\mathrm{C}$. A synopsis of some mean concentrations plus the parameters measured is included in Table 2. Table 3 presents summary data from the larger study (1982), for which organic and mutagenicity data were available. For a detailed description of the sampling and chemical and biological assay techniques, the reader should examine Ramdahl et al $(1982,1984)$. All of the experimental data are contained in the former reference; the latter includes brief summaries of the procedures plus average experimental results stratified 
TABLE 2

Design of the Elverum study

(Winter 1981-82)

\begin{tabular}{|c|c|c|c|}
\hline & $\begin{array}{c}\text { Particles } \\
\left(\mu \mathrm{g} / \mathrm{m}^{3}\right)\end{array}$ & $\begin{array}{c}\text { PAH } \\
\left(\mathrm{ng} / \mathrm{m}^{3}\right)\end{array}$ & $\begin{array}{c}\mathrm{Pb} \\
\left(\mathrm{ng} / \mathrm{m}^{3}\right)\end{array}$ \\
\hline $\begin{array}{l}\text { - Mean concentrations: } \\
\text { Elverum }(1982) \\
\text { Oslo }(1979 ; 1980) \\
\text { [St Olavs plass] } \\
\text { - Observations: } \\
\text { Meteorology (wind } \\
\text { Respirable particle } \\
\text { Inorganic (SO } \\
\text { Carbonaceous (C, } \\
\text { Mutagenicity }\end{array}$ & $\begin{array}{l}51 \\
60 \\
\text { on; temper } \\
\text { PAH, othe } \\
\text { Pi, Cr, }\end{array}$ & $\begin{array}{l}158 \\
149\end{array}$ & $\begin{array}{r}280 \\
1500\end{array}$ \\
\hline
\end{tabular}

according to temperature regimes ("cold" [average ca $-13^{\circ} \mathrm{C}$ ] and "mild" [average ca $\left.-0.5^{\circ} \mathrm{C}\right]$ ).

Significant conclusions deriving from these two tables are: 1) Aerosol and PAH concentrations are similar in Elverum and Oslo, despite their considerable population difference; the difference in $\mathrm{Pb}$ concentrations, however, mirrors the population difference, and suggests that a much larger fraction of the particles arose from motor vehicles in Olso. The missing mass balance (source of non-vehicular particles in Elverum) was a principal reason for introducing ${ }^{14} \mathrm{C}$ measurements for estimation of the $R W C$ contribution. 2) The PAH inventory suggests that wood burning is the dominant wintertime source; the experimental $\left({ }^{14} \mathrm{C}\right)$ evaluation of the relative RWC contribution to aerosol carbon gives an equivalent average value. 3) All of the carbonaceous material (total carbon, wood carbon, retene, PAH), fine particle concentration and mutagenicity are strongly intercorrelated, with somewhat weaker correlation being observed with $\mathrm{Pb}$ (vehicle tracer) and $\mathrm{K}$ (presumed RWC tracer).

\section{${ }^{14} \mathrm{C}$ Variations}

Important insight can be gained from the average concentrations and correlations discussed above, but much more can be learned by a more detailed examination of the quantitative, multivariate structure of the sys-

TABLE 3

Elverum-Winter, 1982

(Ramdahl et al, 1984)

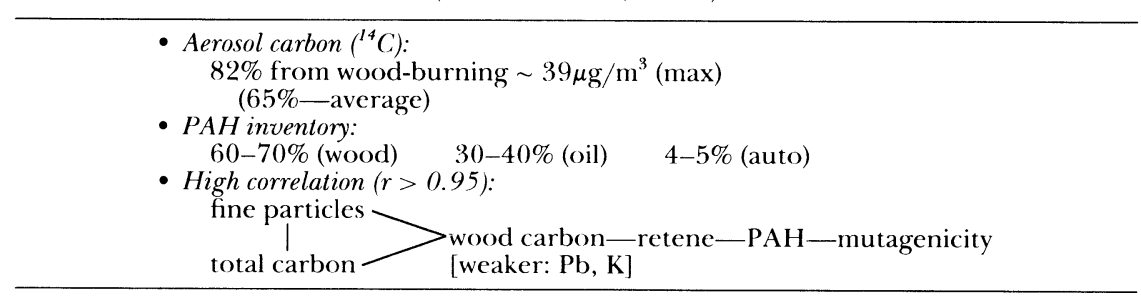


tem, eg, the variations of fossil carbon [FC] and contemporary carbon [CC] with time, temperature, and other chemical species. (FC and CC are more interesting to examine than total carbon and ${ }^{14} \mathrm{C} /{ }^{12} \mathrm{C}$, from which they are derived, in that FC and CC represent the directly emitted material.) Figure 2 shows an initial subdivision according to ambient temperature [y-axis] and selected species [x-axis]. The ordinate represents the ratio of pooled cold $\left(-13^{\circ} \mathrm{C}\right)$ to pooled mild $\left(-0.5^{\circ} \mathrm{C}\right)$ concentration data for January and February 1982, as temperature is believed to be the most significant factor in influencing the fuel mix. Note that the fine particle mass has been decomposed into 3 classes, NC (non-carbonaceous), FC and CC. This gives considerable insight beyond the high correlation seen (Table 3) among fine particles, total carbon, and wood carbon. In fact, we see that $\mathrm{NC}$ and $\mathrm{FC}$ are only slightly affected by temperature, whereas $\mathrm{CC}$ shows a very large increase with decreasing temperature. Of special interest is the fact that the quantitative increase for $\mathrm{CC}$ is comparable to that of the $\mathrm{PAH}$ - suggesting that the bulk of the PAH originates from wood burning. Potassium, the presumed surrogate tracer for wood burning, shows no significant departure from $\mathrm{NC}$ and $\mathrm{FC}$; and $\mathrm{Pb}$, the vehicular tracer, shows a small positive departure. Note that absolute concentration ratios (cold/mild) may be

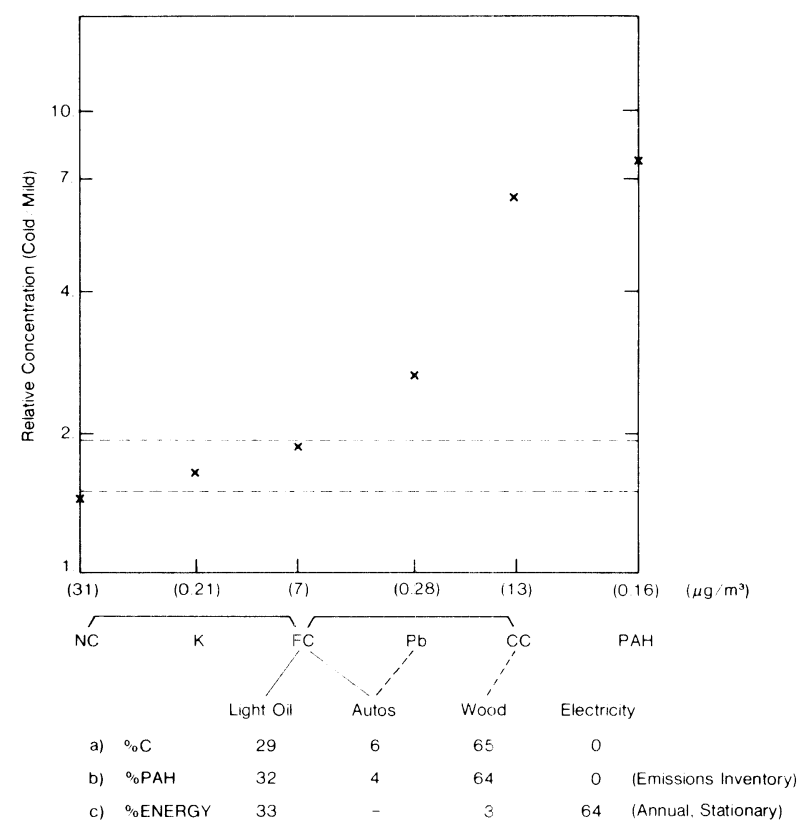

Fig 2. Relative concentrations (cold/mild) for six classes of aerosol species. Just below the abscissa, which simply represents the six classes, are given the respective average wintertime atmospheric concentrations. Below the class symbols [NC ... PAH] thrce types of apportionment data appear: a) combustion carbon source apportionment ("receptor modeling") derived from the observed tracer concentrations [FC, Pb, CC], b) emissions inventory source apportionment for aerosol $\mathrm{PAH}$, and c) annual inventory apportionment for stationary energy consumption. The dashed lines indicate the approximate relative uncertainties $[ \pm$ standard error] for the cold/mild concentration ratios. 
affected by meteorologic factors in addition to temperature, $i e$, the effective local atmospheric dilution volume will depend on atmospheric stability class, wind speed, etc. Therefore, differences in the ratios displayed in Figure 2 carry the most direct information on relative fuel use. In this context, $\mathrm{NC}-\mathrm{K}-\mathrm{FC}$ can be viewed as a base line.

An apportionment of the fine particle carbon among its three principal sources can be made using the average tracer concentrations given along the abscissa of Figure 2. That is, FC, Pb, and CC concentrations can be transformed directly into the percentages of total aerosol carbon originating from light oil combustion, vehicles, and wood burning, as given in the tabulation at the base of the figure. Comparison of this Receptor Modeling estimate of total aerosol carbon apportionment with the following line (\% PAH) is most interesting, in that the PAH apportionment was based on the winter season inventory of relative emissions (Ramdahl et al, 1982). Finally, the bottom line indicates the relatively small contribution of RWC to the annual stationary energy consumption, in contrast with its substantial effect on the winter-time carbon in the atmosphere.

Figures 3 and 4 exhibit more of the multivariate nature of the ${ }^{14} \mathrm{C}$ data. Figure 3, eg, gives a hint of the behavior in five dimensions. Clearly seen is the increase in total (fine particle) aerosol carbon with decreasing ambient temperature, and the increased fraction of that carbon which derives from wood burning. The dramatic excursion from the general trend is seen to be associated with time (over a weekend) and meteorology (calm wind). Another dramatic excursion in the multivariable data has been attributed to long-range transport (Ramdahl et al, 1984); it is characterized by extrema (maxima) for concentrations of sulfate, $\mathrm{K}$, and the transition metals [Mn, Ni, Cr, V] and near minima for fossil and contemporary carbon. Figure 4 gives further insight into the relationships among FC, CC, and $\mathrm{K}$. Although the potassium was moderately correlated with aerosol carbon on the average, $\hat{\rho}=0.88$ (Ramdahl et al, 1982), the more complete FC, CC patterns in Figure 4 indicate that there are two kinds of K: one showing

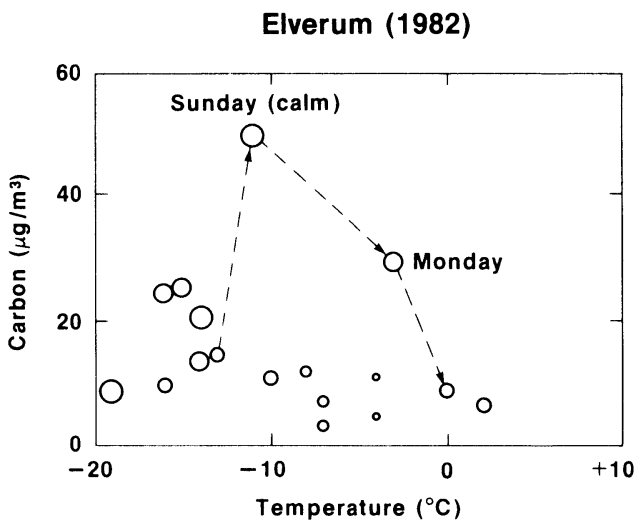

Fig 3. Variation of ${ }^{14} \mathrm{C}$ with temperature, aerosol carbon, time, and wind condition. ${ }^{14} \mathrm{C}$ concentrations are grouped into five levels representing $20 \%$ (of contemporary carbon) increments, where increasing circle size corresponds to increasing ${ }^{14} \mathrm{C}$ level. 
ELVERUM (1982)
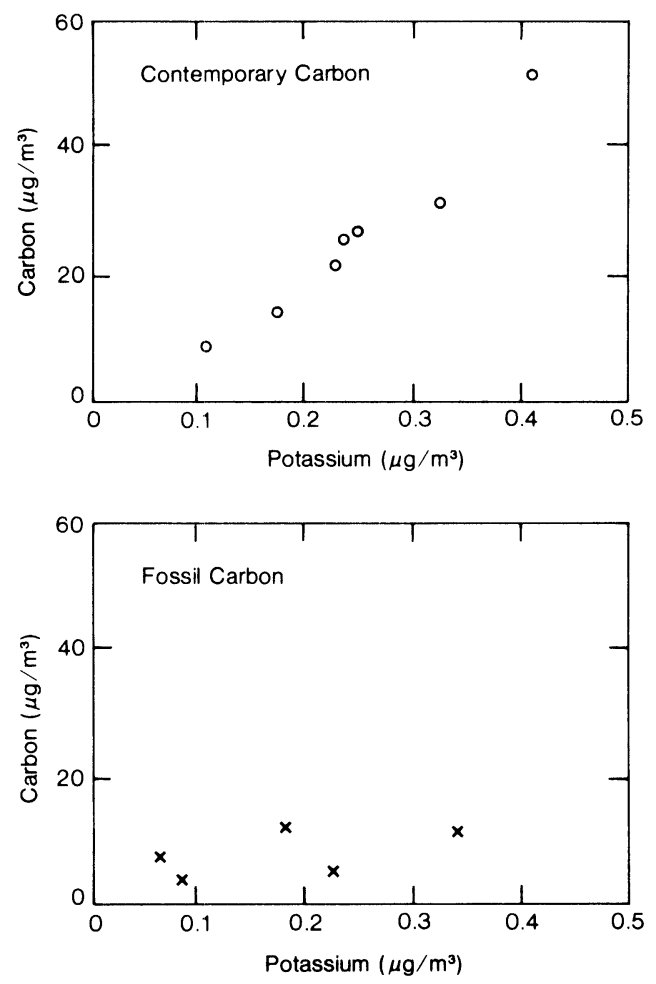

Fig 4. Aerosol carbon vs aerosol potassium (fine particles) stratified for predominantly contemporary $[\mathrm{o}]$ and predominantly fossil $[\mathrm{x}]$ carbon. Stratification was made using samples contained in the upper and lower two ${ }^{14} \mathrm{C}$ concentration levels, respectively.

strong C-correlation, the other showing little C-correlation. This latter figure thus demonstrates, 1) the importance of employing the direct tracer $\left({ }^{14} \mathrm{C}\right)$ for $R W C$, particularly in combination with chemical and meteorologic data, and 2) the danger of using an assumed unique surrogate tracer, together with average measures of relationships (correlation coefficient).

\section{CONCLUSION}

Radiocarbon measurements, performed with miniature gas counters, have demonstrated that the bulk of the fine particle aerosol carbon, found in Elverum during the winter, originates from wood burning. The RWC contribution is important, from the standpoint of pollution, in that it accounted on the average for $65 \%$ of the aerosol carbon, and its absolute contribution attained a maximum of $39 \mu \mathrm{g} / \mathrm{m}^{3}$. Apart from the average statistics, quite important information derives from the multivariate design of the study, where ${ }^{14} \mathrm{C}$ was measured as a function of time, temperature, and inorganic and organic particle composition. These multi-dimensional data have demonstrated, eg, that RWC carbon and PAH behave similarly with ambient temperature, and that fine particle potassium has at least two 
sources. The first observation suggests that the PAH emission from RWC may be even more significant than previously suspected. Direct measurements of ${ }^{14} \mathrm{C}$ in the PAH fraction, such as have been performed with gas counters and accelerators (Currie, Klouda \& Voorhees, 1984; Klouda et al, 1984), are thus very important to assign the origin of this toxic component. The second observation underlines the danger of applying surrogate tracers the assumptions of which have not been fully validated. In analogy with the pitfall associated with the use of fine particle $\mathrm{K}$ as a simple RWC tracer, shown in this study, other surrogates also must be viewed with caution. Methylchloride, eg, also has been considered an RWC tracer (Edgerton, Khalil \& Rasmussen, 1984), but in one recent study it predicted a woodburning particle concentration that exceeded the total particle concentration by more than a factor of 3, in ambient Las Vegas air (Naylor, 1985). Because of its firm theoretical base as a fossil-biospheric carbon discriminator, and especially with the ability to measure mg and sub-mg sample sizes, ${ }^{14} \mathrm{C}$ has become the tracer of choice for the investigation of multi-source carbonaceous pollution problems, such as that existing in Elverum, Norway.

\section{REFERENCES}

Air Pollution Control Association, 1982, Residential wood and coal combustion, SP-45: Pittsburgh, Air Pollution Control Assoc

Cooper, J A and Malek, D, eds, 1982, Residential solid fuels: Beaverton, Oregon Graduate Center.

Currie, L A, Gerlach, R W, Klouda, G A, Ruegg, F C and Tompkins, G B, 1983, Miniature signals and miniature counters: accuracy assurance via microprocessors and multiparameter control techniques, in Stuiver, $\mathrm{M}$ and $\mathrm{Kra}, \mathrm{R} \mathrm{S}$, eds, Internatl ${ }^{14} \mathrm{C}$ conf, 11 th, Proc: Radiocarbon, v 25, no. 2, p 553-564.

Currie, L A, Klouda, G A and Cooper, 1980, Mini-radiocarbon measurements, chemical selectivity, and the impact of man on environmental pollution and climate, in Stuiver, $\mathrm{M}$ and Kra, R S, eds, Internatl ${ }^{14} \mathrm{C}$ conf, 10 th, Proc: Radiocarbon, v 22, no. 2, p 349-362.

Currie, L A, Klouda, G A and Voorhees, K J, 1984, Atmospheric carbon: the importance of accelerator mass spectrometry, in Wölfli, W, Polach, H A, and Andersen, $\mathrm{H} \mathrm{H}$, eds, Internatl symposium on AMS, 3rd, Proc: Nuclear Instruments \& Methods, v 233 [B5], p 371379.

Edgerton, S, Khalil, M and Rasmussen, R, 1984, Estimates of air pollution from backyard burning: Jour Air Pollution Control Assoc, v 34, p 661 .

Klouda, G A, Currie, L A, Donahue, D J, Jull, T and Zabel, T H, 1984, Accelerator mass spectrometry sample preparation: methods for ${ }^{14} \mathrm{C}$ in $50-1000 \mu \mathrm{g}$ samples, in Wölfli, W, Polach, H A, and Andersen, H H, eds, Internatl symposium on AMS, 3rd, Proc: Nuclear Instruments \& Methods, v 233 [B5], p 265.

Lipfert, F W and Dungan, J L, 1983, Residential firewood use in the US: Science, v 219, p 1425-1427.

Naylor, M H, 1985, Air pollution from fireplaces in Las Vegas, Nevada: Las Vegas, Clark Co Health Dist rept.

Ramdahl, T, 1983, Retene-a molecular marker of wood combustion in ambient air: Nature, v 306 , p 580 .

Ramdahl, T, Schjoldager, J, Currie, L A, Hanssen, J E, M $\varnothing$ ller, M, Klouda, G A and Alfheim, I, 1984, Ambient impact of residential wood combustion in Elverum, Norway: Sci Total Environment, v 36, p 81-90.

Ramdahl T, Schjoldager J, Hanssen, J E and M $\varnothing$ ller, M, 1982, Luftforurensning frå vedfyring, malinger i Elverum vintrene 1981 og 1982: Lillestr $\phi \mathrm{m}$, Norwegian Inst Air Research, Rept no. $820136-1$.

Stevens, R K and Pace, F, 1984, Overview of the mathematical and empirical receptor models workshop (Quail Roost II): Atm Environment, v 18, p 1499.

Zak, B D, Einfeld, W, Church, H W, Gay, G T, Jensen, A L, Trijonis, J, Ivey, M D, Homann, P S and Tipton, C, 1984, The Albuquerque winter visibility study: Albuquerque, Sandia Natl Labs, Rept Sand 84-0173. 